\title{
Influence of the Nutritional Aspects on Initial Growth of African Mahogany (Khaya ivorensis A. Chev.)
}

\author{
Camila Oliveira Muniz ${ }^{1}$, Eliana Paula Fernandes Brasil ${ }^{1}$, Lucas Morais Lobo ${ }^{1}$, Evaldo de Melo Ferreira ${ }^{1}$, \\ João Augusto da Silva ${ }^{1}$, Juliana Oliveira da Silva ${ }^{2}$, Ivandilson Pessoa Pinto de Menezes ${ }^{2} \&$ Guilherme Malafaia $^{2}$ \\ ${ }^{1}$ Programa de Pós-graduação em Agronomia, Universidade Federal de Goiás, Campus Samambaia, Goiânia, GO, \\ Brazil \\ ${ }^{2}$ Programa de Pós-graduação em Conservação de Recursos Naturais do Cerrado, Laboratório de Pesquisas \\ Biológicas, Instituto Federal Goiano, Urutaí, GO, Brazil \\ Correspondence: Ivandilson Pessoa Pinto de Menezes, Programa de Pós-graduação em Conservação de Recursos \\ Naturais do Cerrado, Laboratório de Pesquisas Biológicas, Instituto Federal Goiano, Urutaí, GO, Brazil. Tel: \\ 55-64-9279-9708. E-mail: ivan.menezes@ifgoiano.edu.br
}

Received: March 13, 2018

Accepted: Arpil 12, $2018 \quad$ Online Published: May 15, 2018

doi:10.5539/jas.v10n6p184

URL: https://doi.org/10.5539/jas.v10n6p184

The research is financed by Universidade Federal de Goiás and Instituto Federal Goiano.

\begin{abstract}
Khaya ivorensis A. Chev. (African mahogany) is one of the most economically important forest species, since it is used in the international furniture market. However, little is known about its culture and nutritional requirements. This study aimed to assess the development of $\mathrm{K}$. ivorensis plants subjected to different base saturations, as well as to different N, P and K levels. An 8-ha area was used, wherein 4 ha had base saturation increased to $55 \%$ and the remaining 4 ha to $75 \%$. The experimental design adopted was randomized blocks with eight repetitions in a factorial scheme $(4 \times 4 \times 4)$, being four $\mathrm{N}$ doses, four $\mathrm{P}$ doses and four $\mathrm{K}$ doses. The base saturation was assessed through the block effect. The root collar diameter and the plant height were measured 12 months after planting. Each experimental plot comprised six plants. The root collar diameter showed statistical differences between blocks and N doses. Only the NPK association showed statistical variation in plant height. However, a growth decreasing trend resulting from increased $\mathrm{N}$ doses was observed, as well as a growth increasing trend resulting from increased $\mathrm{P}$ and $\mathrm{K}$ doses. All treatments favored African mahogany growth. The most indicated base saturation was 55\%, since there was no plant growth improvement when V\% was increased to $75 \%$. The excess of $\mathrm{N}$ impaired the growth of the species. The best treatment comprised $60 \mathrm{~g}$ urea, $240 \mathrm{~g}$ triple superphosphate, and $168 \mathrm{~g}$ potassium chloride.
\end{abstract}

Keywords: plants' mineral nutrition, forest species, plant growth, hardwood

\section{Introduction}

Meliaceae is an important hardwood family, which comprises the most valuable tropical timbers in the world (Ravindran, 2018). Genera such as Swietenia sp., Cedrella sp., Toona sp., Khaya sp., among others, belong to this family. The restriction on the cutting and trade of timber derived from native trees resulted in the expanded cultivation of exotic tree species such as the African mahogany (Nikler et al., 2008; Karan et al., 2012).

Brazil has considerably grown despite the recent global economic crisis, and the forestry sector productive chain accounts for part of this growth. According to Associação Brasileira de Produtores de Florestas Plantadas (ABRAF), the total area planted with forests in Brazil was 7,185,943 ha in 2012 (ABRAF, 2013). In addition, the Brazilian forest product market accounted for US\$ 7.54 billion of the national exports in that same year.

The depletion of native forests and the high demand for timber have sparked the interest of rural producers in investing in forest monoculture. According to Serviço Florestal Brasileiro (SFB) and Instituto de Pesquisa Ambiental da Amazônia (IPAM), the average demand for timber derived from native forests was estimated at 21 million $\mathrm{m}^{3}$ year $^{-1}$ (SFB \& IPAM, 2011). Thus, it would be necessary planting a 36 million ha area over a 30 -year cycle in order to meet this demand. 
The genus Khaya sp., which is popularly known as African mahogany, has been indicated for commercial plantations due to its excellent adaptation to the Brazilian edaphoclimatic conditions and to its high value in the international market (Ribeiro et al., 2016, 2017). Its wood shows reddish color and relatively-low density, which are features required by the furniture industry (Falesi \& Baena, 1999; Nikler et al., 2008). In addition, it is highly resistant to Hypsipyla grandella, which is a pest species limiting the cultivation of Swietenia macrophylla King (popularly known as Brazilian mahogany) (Zanetti et al., 2017). Khaya ivorensis is one of the species reforesters seek the most. It grows up to $40 \mathrm{~m}^{-3} \mathrm{ha}^{-1}$ year ${ }^{-1}$ under favorable conditions, and the cubic meter of sawn timber may exceed US\$ 2,000.00 (Lemmens, 2008). Given the productive potential of the African mahogany species in Brazil, it is necessary conducting studies in order to characterize and improve this species.

Fertilization is the most common and perhaps the most effective cultural practice used to improve the quality of forest species (Turner et al., 2018). According to Santana et al. (2002), setting economically viable forests requires knowing the sylvicultural practices to be adopted, in details. The climatic conditions in Brazil enable a long growing season, differently from temperate regions, where most of the agricultural technique recommendations used in the country come from. Accordingly, it is necessary "tropicalizing" these techniques, and this concept is perfectly suited to the use of fertilizers (Benites et al., 2010).

Thus, thinking that soil correction and fertilization have been widely studied is a very common mistake, since several practices need to be reviewed and adapted to each crop and soil type, mainly when it comes to forestry. The fertilization conducted according to the specific nutritional needs of the crop is able to provide increased timber productivity with reduced investment, as well as to cause minimum environmental impact (Moreno et al., 2017). Therefore, the aim of the present study was to assess the effect of base saturation, as well as of different nitrogen $(\mathrm{N})$, phosphorus $(\mathrm{P})$ and potassium $(\mathrm{K})$ levels, on the initial growth of African mahogany (Khaya ivorensis) seedlings. It is believed that the current study may be useful to the practices to be adopted in the cultivation of the herein investigated species in Cerrado soils, since it is the first study assessing how nutritional aspects may influence the initial growth of an important forest species.

\section{Material and Methods}

\subsection{Experimental Station}

The present study was developed at Hiroshi Okajima Experimental Station, Bonfinópolis County, Goiás State, Brazil. The region is located at latitude $16^{\circ} 35^{\prime} 37.32^{\prime \prime}$ South, longitude $49^{\circ} 1^{\prime} 56.13^{\prime \prime}$ West, and altitude $780 \mathrm{~m}$. According to the Köppen-Geiger's classification, the climate in the region is Aw, tropical, megathermal, with summer rains and no winter. The mean temperature in the coldest month remains above $18{ }^{\circ} \mathrm{C}$, whereas the annual rainfall is higher than the annual potential evapotranspiration.

The experiment was conducted in an 8 -ha area, which had been previously used as pasture and showed $6 \%$ slope. The soil sampling was performed in the total area for chemical and textural analysis, before the experiment was conducted at the depths 0-20 cm and 20-40 cm (Table 1). The soil was classified as Dystrophic Red Latosol, with clay loam texture. 
Table 1. Chemical attributes and soil texture resulting from the sample collected in the total area before the experiment and after the localized application of $600 \mathrm{~kg} \mathrm{ha}^{-1}$ and $1800 \mathrm{~kg} \mathrm{ha}^{-1}$ limestone, at the depths $0-20 \mathrm{~cm}$ and 20-40 cm, at Hiroshi Okajima Experimental Station, Bonfinópolis (GO, Brazil)

\begin{tabular}{|c|c|c|c|}
\hline Attributes & Measurement units & $0-20 \mathrm{~cm}$ & $20-40 \mathrm{~cm}$ \\
\hline $\mathrm{Ca}+\mathrm{Mg}$ & \multirow{7}{*}{$\mathrm{cmol}_{\mathrm{c}} \mathrm{dm}^{-3}$} & 2.2 & 1.1 \\
\hline $\mathrm{Ca}$ & & 1.7 & 0.8 \\
\hline $\mathrm{Mg}$ & & 0.5 & 0.3 \\
\hline $\mathrm{Al}$ & & 0.0 & 0.0 \\
\hline $\mathrm{H}+\mathrm{Al}$ & & 2.9 & 3.0 \\
\hline $\mathrm{K}$ & & 0.1 & 0.06 \\
\hline CTC (T) & & 5.22 & 4.17 \\
\hline $\mathrm{K}$ & \multirow{9}{*}{$\mathrm{mg} \mathrm{dm}$} & 40.0 & 24 \\
\hline $\mathrm{P}(\mathrm{Mel})$ & & 1.3 & 1.7 \\
\hline S & & 2.0 & 2.0 \\
\hline $\mathrm{Na}$ & & 5.0 & 3.0 \\
\hline $\mathrm{Zn}$ & & 0.6 & 0.1 \\
\hline $\mathrm{B}$ & & 0.17 & 0.15 \\
\hline $\mathrm{Cu}$ & & 3.0 & 2.8 \\
\hline $\mathrm{Fe}$ & & 62.4 & 62.3 \\
\hline Mn & & 32.0 & 22.4 \\
\hline $\mathrm{V}$ & \multirow{2}{*}{$\%$} & 44.48 & 28.13 \\
\hline M & & 0 & 0 \\
\hline $\mathrm{OM}$ & \multirow{2}{*}{$\mathrm{g} \mathrm{dm}^{-3}$} & 27.00 & 23.00 \\
\hline $\mathrm{OC}$ & & 15.66 & 13.34 \\
\hline Sand & \multirow{3}{*}{$\mathrm{g} \mathrm{kg}^{-1}$} & 54 & 59 \\
\hline Silt & & 90 & 90 \\
\hline Clay & & 370 & 320 \\
\hline $\mathrm{pH}(\mathrm{CaCl})$ & 5.2 & 5.1 & \\
\hline
\end{tabular}

Note. V: base saturation. M: aluminum saturation. OM: organic matter. OC: organic carbon.

The area was divided in 8 blocks. The soil analysis results were used to calculate the amount of limestone required to increase the base saturation (V\%) to $55 \%$ and $75 \%$. Thus, $600 \mathrm{~kg} \mathrm{ha}^{-1}$ of dolomitic limestone were applied and incorporated to blocks 1 to 4 , whereas $1800 \mathrm{~kg} \mathrm{ha}^{-1}$ of it were applied and incorporated to blocks 5 to 8 , as shown in Figure 1. The entire area received $600 \mathrm{~kg} \mathrm{ha}^{-1}$ gypsum; $500 \mathrm{~kg} \mathrm{ha}^{-1}$ of reactive phosphate were applied to the planting rows during the subsoiling process.

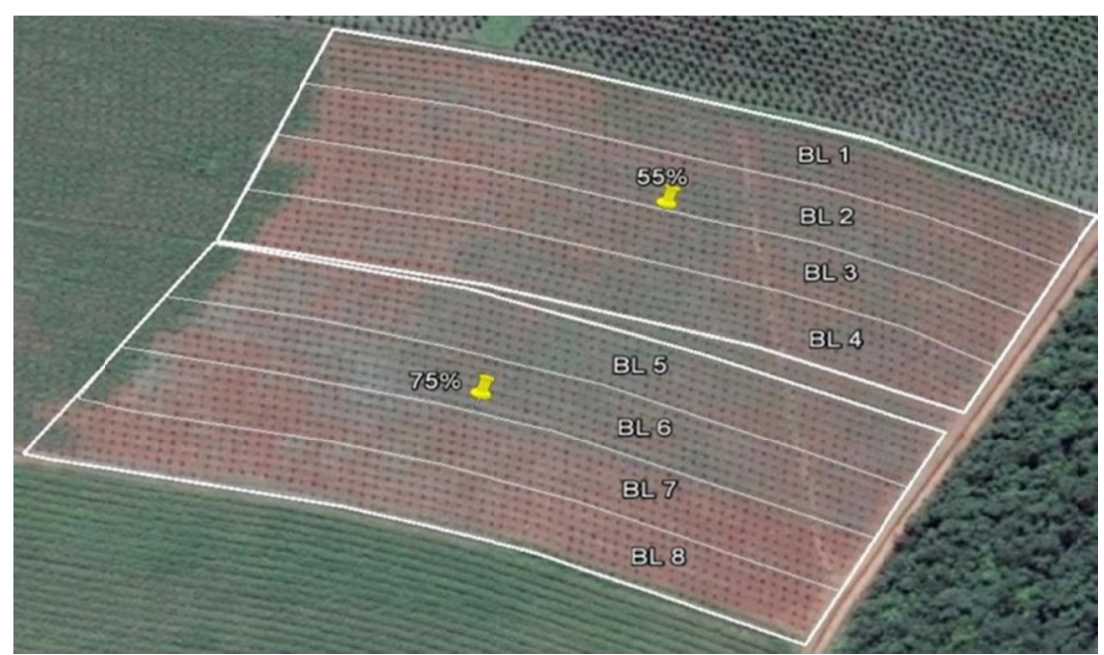

Figure 1. Experimental area divided in two base saturations, and block positioning at Hiroshi Okajima Experimental Station (Bonfinópolis, GO, Brazil) 
Then, 3,120 African mahogany (Khaya ivorensis A. Chev.) seminal seedlings showing mean height $33 \mathrm{~cm}$ and root collar diameter of approximately $6 \mathrm{~mm}$ were planted. The herein adopted spacing was $5.0 \times 5.0 \mathrm{~m}$, and the density was 400 plants/hectare. Soon after planting, 20 grams of NPK (10-30-10 per plant) were applied to side pits. As the planting was carried out during the dry period (June 2013), it was necessary supplying water to the plants through a small water cart coupled to a tractor. Each plant received $10 \mathrm{~L}$ of water every three days, during the first month; the first three watering procedures used $250 \mathrm{~g}$ hydrogel $/ 5000 \mathrm{~L}$ water. The plants received the same water volume once a week, between July and October. The watering was performed on a weekly basis, during the Indian summers, using $5 \mathrm{~L}$ of water per plant. New soil sampling was carried out during the rainy season in 2014 in order to assess the base saturation after the limestone application. The data are shown in Table 2.

Table 2. Soil analysis results after the localized application of $600 \mathrm{~kg} \mathrm{ha}^{-1}$ and $1800 \mathrm{~kg} \mathrm{ha}^{-1}$ limestone, at the depths 0-20 cm and 20-40 cm, at Hiroshi Okajima Experimental Station (Bonfinópolis, GO, Brazil)

\begin{tabular}{|c|c|c|c|c|c|}
\hline \multirow{2}{*}{ Attributes } & \multirow{2}{*}{ Measurement units } & \multicolumn{2}{|c|}{$600 \mathrm{~kg}, \mathrm{Jan} / 14$} & \multicolumn{2}{|c|}{$1800 \mathrm{~kg}, \mathrm{Jan} / 14$} \\
\hline & & $0-20 \mathrm{~cm}$ & $20-40 \mathrm{~cm}$ & $0-20 \mathrm{~cm}$ & $20-40 \mathrm{~cm}$ \\
\hline $\mathrm{Ca}+\mathrm{Mg}$ & \multirow{7}{*}{$\mathrm{cmol}_{\mathrm{c}} \mathrm{dm}^{-3}$} & 3.4 & 2.90 & 6.30 & 5.20 \\
\hline $\mathrm{Ca}$ & & 2.5 & 2.1 & 4.4 & 3.8 \\
\hline $\mathrm{Mg}$ & & 0.9 & 0.8 & 1.9 & 1.4 \\
\hline $\mathrm{Al}$ & & 0 & 0.01 & 0 & 0 \\
\hline $\mathrm{H}+\mathrm{Al}$ & & 2.8 & 2.4 & 2.1 & 2.5 \\
\hline $\mathrm{K}$ & & 0.13 & 0.11 & 0.15 & 0.13 \\
\hline CTC (T) & & 6.36 & 5.41 & 8.58 & 7.53 \\
\hline $\mathrm{K}$ & \multirow{9}{*}{$\mathrm{mg} \mathrm{dm}{ }^{-3}$} & 50 & 42 & 57 & 52 \\
\hline $\mathrm{P}(\mathrm{Mel})$ & & 2.1 & 3.4 & 2.4 & 1.8 \\
\hline $\mathrm{S}$ & & 3.4 & - & 7.1 & - \\
\hline $\mathrm{Na}$ & & 8 & - & 8 & - \\
\hline $\mathrm{Zn}$ & & 0.5 & 0.4 & 0.4 & 0.8 \\
\hline B & & 0.19 & - & 0.23 & - \\
\hline $\mathrm{Cu}$ & & 4 & - & 3.1 & - \\
\hline $\mathrm{Fe}$ & & 60.1 & - & 60.6 & - \\
\hline $\mathrm{Mn}$ & & 37.3 & - & 52.1 & - \\
\hline $\mathrm{V}$ & \multirow{2}{*}{$\%$} & 56.05 & 55.64 & 75.58 & 68.07 \\
\hline M & & 0.00 & 3.22 & 0 & 0 \\
\hline $\mathrm{OM}$ & \multirow{2}{*}{$\mathrm{g} \mathrm{dm}^{-3}$} & 48 & 35 & 35 & 29 \\
\hline $\mathrm{OC}$ & & 27.84 & 20.3 & 20.3 & 16.82 \\
\hline Sand & \multirow{3}{*}{$\mathrm{g} \mathrm{kg}^{-1}$} & 50.00 & - & - & - \\
\hline Silt & & 10 & - & - & - \\
\hline Clay & & 40 & - & - & - \\
\hline $\mathrm{pH}(\mathrm{CaCl})$ & & 5.20 & 4.9 & 5.8 & 5.5 \\
\hline
\end{tabular}

Note. V: base saturation. M: aluminum saturation. OM: organic matter. OC: organic carbon.

\subsection{Crop Handling}

Periodic cleanings were conducted in the study area during the experiment. They consisted of two mechanical weeding procedures using a tractor pulling a harrowing grid between the rows. Chemical weeding's carried out between plants using glyphosate $\left(3 \mathrm{~L} \mathrm{ha}^{-1}\right)$ and flumizin $\left(100 \mathrm{~g} \mathrm{ha}^{-1}\right)$. The plants were subjected to manual weeding in an $80-\mathrm{cm}$ radius from the stem, before each top-dressing fertilization. Pest monitoring was continuously carried out. Leaf-cutting ants were controlled by applying formicide bait and fipronil $\left(80 \mathrm{~g} \mathrm{ha}^{-1}\right)$. With respect to plants presenting lateral sprouting, the most rectilinear sprout was chosen and the others were removed using pruning shears.

\subsection{Conducting the Experiment}

The study was conducted in an African mahogany commercial forest, during the second implantation month. Treatments combining 4 nitrogen $(\mathrm{N}), 4$ phosphorus $(\mathrm{P})$, and 4 potassium $(\mathrm{K})$ doses were set. There were 64 treatments, in total, according to the composition shown in Figure 2. 


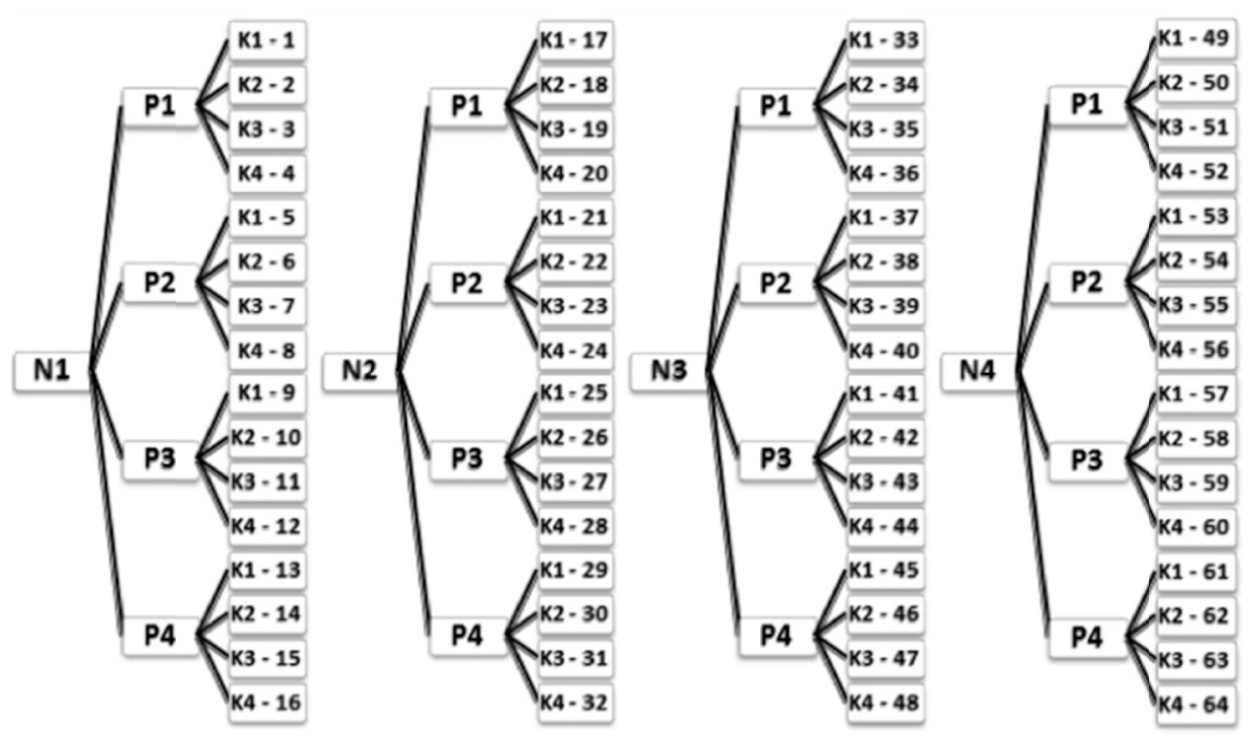

Figure 2. Composition of the treatments conducted according to the herein described factorial scheme, through the combination of nitrogen, phosphorus and potassium doses at Hiroshi Okajima Experimental Station

(Bonfinópolis, GO, Brazil)

The experimental design followed randomized complete blocks; 4 blocks were allocated in the treated area to obtain $55 \%$ base saturation, whereas 4 blocks were allocated to obtain $75 \%$ base saturation. Each block was composed of 6 rows, with 11 plots each. The blocks were randomized through the drawing of plots within the block. The experiment comprised 512 experimental plots with 6 plants each. Concurrently, 6 non-fertilized plots were selected and subjected to the Tukey test in order to compare their means to the means of the other treatments.

Nitrogen, phosphorus and potassium were supplied to the plants through urea, triple superphosphate and potassium chloride. Sulfur, boron, manganese and zinc were supplied to the plants in each fertilization through FTE application at 5\% the amount of NPK applied per plant. The fertilization was divided in 4 applications, one every two months, as described in Appendix 1.

The first fertilization was carried out in August $/ 2015$, when the plants had mean height $39.0 \mathrm{~cm}$ and root collar diameter $7.8 \mathrm{~mm}$. The fertilizer was applied to two lateral pits $20 \mathrm{~cm}$ away from the plant stem and $15 \mathrm{~cm}$ deep; it was reapplied in October of the same year. The other fertilizations were carried out in December 2013 and in February 2014. As the amount of fertilizers was doubled, the application was carried out in two lateral furrows ( $30 \mathrm{~cm}$ long and $15 \mathrm{~cm}$ deep) $40 \mathrm{~cm}$ away from the plants.

The parameters assessed in the current study were seedling total height and root collar diameter. The assessments were carried out after each fertilization period. A measuring tape was used to measure plant height, whereas a digital caliper was used to collect the root collar diameter data. The plants' behavior towards different base saturations (V\%) was assessed through the block effect.

\subsection{Statistical Analyses}

All data were initially subjected to the Anderson-Darling normality test, which was followed by the Levene variance homogeneity test. Next, the data were subjected to analysis of variance (ANOVA) according to the factorial model $4 \times 4 \times 4$, using 4 nitrogen $(\mathrm{N}), 4$ phosphorus $(\mathrm{P})$ and 4 potassium $(\mathrm{K})$ doses. The Tukey test was applied at 5\% probability level in case of significant F. All analyses were performed in the Sanest software (Zonta \& Machado, 1995).

\section{Results and Discussion}

Only the NPK interaction showed statistically significant difference in the variable "height", as shown in Appendix 2. The root collar diameter showed significant differences between $\mathrm{N}$ doses and between blocks. The large number of repetitions adopted in the current experiment and, consequently, the high degree of freedom of the residue allowed seeing small differences as statistically significant. On the other hand, the base saturation 
influence was assessed through the block effect. Table 5 shows the mean total height and root collar diameter of the plants belonging to each block.

Table 5. Mean height, mean root collar diameter and base saturation levels (V\%) in each block planted with 12-month-old African mahogany (Khaya ivorensis) plants, at Hiroshi Okajima Experimental Station, Bonfinópolis (GO, Brazil). Means followed by equal letters in the column do not differ from each other, according to the Tukey test, at 5\% probability level

\begin{tabular}{lll}
\hline Block $(\mathrm{V} \%)$ & Height $(\mathrm{cm})$ & Root collar diameter $(\mathrm{mm})$ \\
\hline $1(55 \%)$ & $214.59 \mathrm{a}$ & $46.90 \mathrm{~b}$ \\
$2(55 \%)$ & $218.92 \mathrm{a}$ & $49.91 \mathrm{a}$ \\
$3(55 \%)$ & $217.95 \mathrm{a}$ & $49.59 \mathrm{a}$ \\
$4(55 \%)$ & $217.17 \mathrm{a}$ & $50.11 \mathrm{a}$ \\
$5(75 \%)$ & $213.62 \mathrm{a}$ & $43.96 \mathrm{c}$ \\
$6(75 \%)$ & $215.96 \mathrm{a}$ & $46.44 \mathrm{~b}$ \\
$7(75 \%)$ & $220.23 \mathrm{a}$ & $49.33 \mathrm{a}$ \\
$8(75 \%)$ & $217.68 \mathrm{a}$ & $51.10 \mathrm{a}$ \\
Mean & 217.30 & 48.32 \\
CV $(\%)$ & 6.92 & 8.02 \\
\hline
\end{tabular}

There was no statistically significant difference in the variable "height" in plants subjected to different base saturation levels. However, the opposite occurred in the variable "root collar diameter". Thus, it is possible assuming that the difference found between blocks may be related to random factors rather than to the herein used treatments. The block design allows greater local control, since this design is appropriate to heterogeneous experimental environments if one wants to control a variation factor. The blocks allows isolating any necessary operational modification from the treatment effect. According to Moretti et al. (2011), the plant diameter development is strongly influenced by plant's genetics. As planting was carried out using seminal seedlings, this variable would not have been affected by treatments yet, as suggested in Table 6 .

Table 6. Mean height and root collar diameter values of 12-month-old African mahogany (Khaya ivorensis) plants subjected to different liming and base saturation (V\%) levels, at Hiroshi Okajima Experimental Station (Bonfinópolis, GO, Brazil)

\begin{tabular}{|c|c|c|c|c|c|}
\hline \multirow{2}{*}{ Blocks } & \multirow{2}{*}{$\mathrm{V} \%$} & \multicolumn{2}{|c|}{ Final V\% } & \multirow{2}{*}{ Heicht $(\mathrm{cm})$} & \multirow{2}{*}{ Root collar diameter (mm) } \\
\hline & & $0-0.20 \mathrm{~m}$ & $0.2-0.40 \mathrm{~m}$ & & \\
\hline 01 to 04 & 55 & 56.05 & 55.64 & 216.2 & 48.9 \\
\hline 05 to 08 & 75 & 75.58 & 68.07 & 216.6 & 47.6 \\
\hline
\end{tabular}

It is possible seeing that the increased application of corrective agents did not lead to plant development during the first year in African mahogany plantations. Among the herein tested limestone doses, it is possible stating that $55 \%$ base saturation is the most economically indicated for Khaya ivorensis development.

According to Favare et al. (2012), liming positively affects the absorption of all macro and micronutrients, except for zinc. The accumulation of nutrients in the shoot of teak plants happens in the following decreasing order: $\mathrm{N}>\mathrm{Ca}>\mathrm{K}>\mathrm{Mg}>\mathrm{P}>\mathrm{S}>\mathrm{Fe}>\mathrm{Mn}>\mathrm{B}>\mathrm{Zn}>\mathrm{Cu}$. The species development and nutrient accumulation apex lies between 60 and 80\% base saturation. Silva et al. (2007) have analyzed maize (Swietenia macrophylla) seedlings subjected to increasing corrective agent doses and found that liming has positively affected N, P, K, Ca, $\mathrm{Mg}, \mathrm{Mn}$ absorption, whereas it negatively affected Fe absorption.

On the other hand, Corcioli et al. (2014) have found that African mahogany plants grown in nutrient solution with $\mathrm{N}$ omission showed lower development, thin stem and small leaves. The 0 dose was not used, in compliance with the experimental data. All the tested doses showed satisfactory plant development, whereas none of the treatments showed visible deficiency symptoms.

The parameter "root collar diameter" showed statistically significant difference between the tested N doses. The treatments using the highest $\mathrm{N}$ doses have negatively influenced plant development, as shown in Table 7. 
Although the statistical values did not show influence of the tested doses on plant height, the plant growth tended to decrease as the $\mathrm{N}$ doses increased. This effect can be seen in Figure $3 \mathrm{~A}$.

Table 7. Height and diameter of 12-month-old African mahogany (Khaya ivorensis) plants subjected to different nitrogen $(\mathrm{N})$ doses, at Hiroshi Okajima Experimental Station (Bonfinópolis, GO, Brazil). Means followed by equal letters in the column do not differ from each other, according to the Tukey test, at 5\% probability level

\begin{tabular}{lll}
\hline N Dose & Height $(\mathrm{cm})$ & Root collar diameter $(\mathrm{mm})$ \\
\hline 60 & $218.00 \mathrm{a}$ & $48.82 \mathrm{a}$ \\
120 & $217.64 \mathrm{a}$ & $48.87 \mathrm{a}$ \\
180 & $216.25 \mathrm{a}$ & $48.72 \mathrm{a}$ \\
240 & $216.18 \mathrm{a}$ & $47.27 \mathrm{~b}$ \\
Control & 162.87 & 36.09 \\
\hline
\end{tabular}
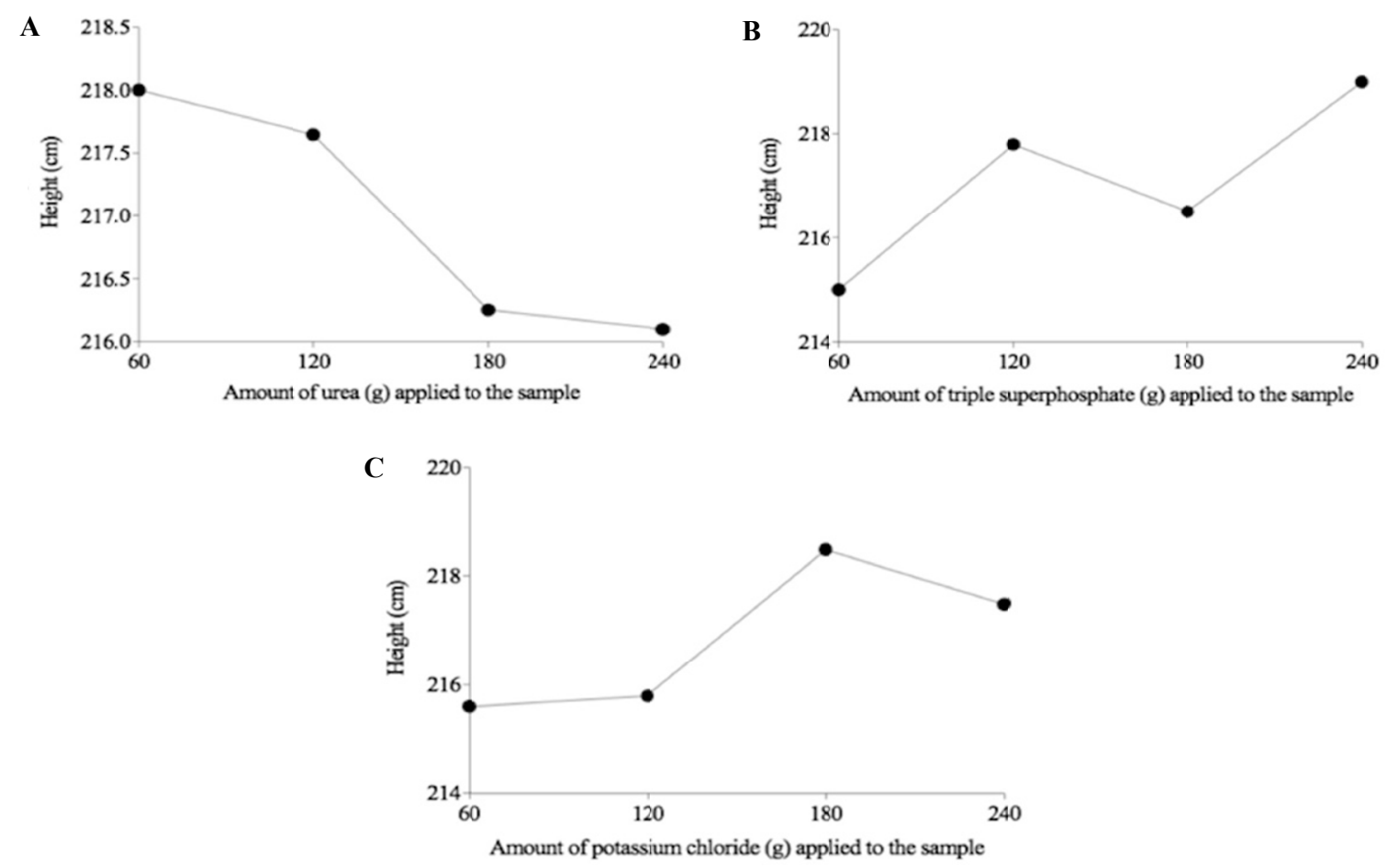

Figure 3. Influence of N (A), P (B) and K (C) doses on the growth of Khaya ivorensis plants during the first twelve months of cultivation at Hiroshi Okajima Experimental Station (Bonfinópolis, GO, Brazil)

The African mahogany (K. ivorensis) plants have demanded less nitrogen in the first development year; they have also shown tolerance to the excess of this nutrient in the crop. Despite the decreased growth resulting from the highest $\mathrm{N}$ doses, none of the plants showed toxicity symptoms. According to Ciriello et al. (2014), guanandi (Calophyllum brasiliensis) plants grew less as the $\mathrm{N}$ doses increased from $33 \mathrm{mg} \mathrm{dm}^{-3}$ on. Each $40 \mathrm{mg} \mathrm{dm}^{-3}$ of $\mathrm{N}$ added to the plants led to $2.9 \mathrm{~mm}$ reduction in stem diameter.

As per Tucci et al. (2009), nitrogen fertilization has positively influenced the growth of S. macrophylla plants. However, the maximum applied dose $\left(240 \mathrm{~kg} \mathrm{t}^{-1}\right.$ of substrate) had negative effect on stem diameter and on shoot dry matter, thus impairing seedling quality; therefore, it is possible suggesting that the recommended $\mathrm{N}$ dose is $57.5 \mathrm{~kg}$ per ton of substrate. Tucci and Pinto (2003) have also found negative influence of high $\mathrm{N}$ doses on the growth of Brazilian mahogany seedlings.

According to Souza et al. (2010), nitrogen did not affect the initial growth of Brazilian mahogany plants. The justification presented was that the organic matter in the soil may have supplied enough $\mathrm{N}$ to the species through the mineralization process. Similarly, Feitosa et al. (2011) have tested different ammonium sulfate, ammonium nitrate and calcium nitrate doses in Astronium fraxinifolium plants and found that the $\mathrm{N}$ source did not influence 
the initial plant development. However, the plant growth decreased when the $\mathrm{N}$ doses exceeded $75 \mathrm{mg} \mathrm{dm}^{-3}$. On the other hand, according to Mews et al. (2015), nitrogen fertilization has positively influenced the growth of yellow ipê (Handroanthus ochraceus) seedlings. Therefore, these data suggest that an adequate nitrogen nutrition improves the $\mathrm{N}$ and $\mathrm{P}$ leaf contents in the studied species, thus increasing plant growth and producing quality seedlings.

It is consensus that phosphorus is a determinant element in plant growth. According to Souza et al. (2012), this nutrient is considerably important to carbon metabolism, as well as to the formation of phosphate sugars. However, despite the significant importance of phosphorus to different crops, the doses tested in the current study did not influence the height and root collar diameter increase in Khaya ivorensis plants. Table 8 shows the mean values of the treatments using different phosphorus doses. Unlike what was observed in the nitrogen fertilization, the highest phosphorus doses tended to result in taller plants, as shown in Figure 3B.

Table 8. Height and diameter of 12-old-month African mahogany (Khaya ivorensis) plants subjected to different phosphorus (P) doses, at Hiroshi Okajima Experimental Station (Bonfinópolis, GO, Brazil). Means followed by equal letters in the column do not differ from each other, according to the Tukey test, at $5 \%$ probability level

\begin{tabular}{lll}
\hline P Dose & Height $(\mathrm{cm})$ & Root collar diameter $(\mathrm{mm})$ \\
\hline 60 & $215.00 \mathrm{a}$ & $47.61 \mathrm{a}$ \\
120 & $217.68 \mathrm{a}$ & $48.76 \mathrm{a}$ \\
180 & $216.64 \mathrm{a}$ & $48.52 \mathrm{a}$ \\
240 & $218.75 \mathrm{a}$ & $48.78 \mathrm{a}$ \\
\hline
\end{tabular}

The current data are similar to those found by Santin et al. (2013), who studied the nutrition of yerba mate (Ilex paraguariensis) plants and found the same responses regardless of the tested doses. However, it was possible stating that the species grows in soils showing high $\mathrm{P}$ content, since it did not show toxicity symptoms resulting from this nutrient.

However, previous studies have found discrepant results regarding the effects of different phosphorus doses on the development of some forest species. According to Tucci et al. (2011), phosphorus addition to the substrate of Brazilian mahogany seedlings did not help increasing biometric parameters, fact that suggests the low potential of the species to respond to P addition during the growth phase. On the other hand, Santos et al. (2008) have applied increasing phosphorus doses to Brazilian mahogany seedlings and found seedling growth increase in all assessed traits (plant height, stem diameter). A study conducted by Moretti et al. (2011) found that phosphorus omission has limited the growth of Australian cedar (T. cilliata) plants. The same result was found by Ciriello et al. (2014) in studies conducted with guanandi (Calophyllum brasiliensis) plants; it was evident that $\mathrm{P}$ was the most important nutrient for the species' root development.

According to Corcioli et al. (2014), African mahogany plants tend to show total growth reduction, as well as reduced leaf-size, when they face lack of potassium. The authors could find chlorosis, which was followed by necrosis in the tips and margins of old leaves.

The potassium doses used in the current study did not lead to statistically significant differences in the assessed biometric parameters. However, it is possible stating that African mahogany plants develop well when they are subjected to small amounts of potassium, as well as that they are quite tolerant to the excess of this nutrient, as shown in Table 9.

Table 9. Height and diameter of 12-month-old African mahogany (Khaya ivorensis) plants subjected to different potassium (K) doses, at Hiroshi Okajima Experimental Station, Bonfinópolis (GO, Brazil). Means followed by equal letters in the column do not differ from each other, according to the Tukey test, at $5 \%$ probability level

\begin{tabular}{lll}
\hline K Dose & Height $(\mathrm{cm})$ & Root collar diameter $(\mathrm{mm})$ \\
\hline 42 & $215.85 \mathrm{a}$ & $47.81 \mathrm{a}$ \\
84 & $215.98 \mathrm{a}$ & $48.34 \mathrm{a}$ \\
126 & $218.76 \mathrm{a}$ & $48.88 \mathrm{a}$ \\
168 & $217.48 \mathrm{a}$ & $48.65 \mathrm{a}$ \\
\hline
\end{tabular}


Plants subjected to the highest potassium doses tended to show better results, which was similar to their response to phosphorus and different from their response to nitrogen (Figure 3C). This result may be explained through the regulation of the African mahogany plant osmotic potential, which reduced the water stress effect during the dry period and during the intense Indian summers in the experimental period.

Finally, the means of each N-P-K combination were subjected to the Tukey test in order to assess the best fertilization to be applied to African mahogany (Khaya ivorensis) plants in the first cultivation year; the test considered each dose combination as an isolated treatment. Appendix 3 summarizes the results of the analysis of variance.

The parameter "plant height" showed significant difference between all treatments, whereas the parameter "root collar diameter" showed differences between the treatments and the control, only (Table 11).

Table 11. Comparison between mean diameter and height of 12-month-old African mahogany (Khaya ivorensis) plants subjected to NPK fertilization at Hiroshi Okajima Experimental Station (Bonfinópolis, GO, Brazil). Means followed by the same letters in the column do not differ from each other, according to the Tukey test, at $5 \%$ probability level

\begin{tabular}{|c|c|c|c|c|c|}
\hline \multirow{2}{*}{$\begin{array}{l}\text { Treatment } \\
0\end{array}$} & \multirow{2}{*}{$\begin{array}{l}\text { NPK combination } \\
0\end{array}$} & \multicolumn{2}{|c|}{ Height $(\mathrm{cm})$} & \multicolumn{2}{|c|}{ Root collar diameter $(\mathrm{mm})$} \\
\hline & & 162.87 & $\mathrm{c}$ & 36.09 & $\mathrm{~b}$ \\
\hline 1 & 111 & 207.87 & $\mathrm{~b}$ & 48.20 & $\mathrm{a}$ \\
\hline 2 & 112 & 209.75 & $\mathrm{ab}$ & 47.35 & $\mathrm{a}$ \\
\hline 3 & 113 & 211.00 & $\mathrm{ab}$ & 49.52 & $\mathrm{a}$ \\
\hline 4 & 114 & 215.87 & $a b$ & 49.10 & $\mathrm{a}$ \\
\hline 5 & 121 & 221.25 & $\mathrm{ab}$ & 48.64 & $\mathrm{a}$ \\
\hline 6 & 122 & 221.87 & $\mathrm{ab}$ & 50.53 & $\mathrm{a}$ \\
\hline 7 & 123 & 218.00 & $a b$ & 48.93 & $\mathrm{a}$ \\
\hline 8 & 124 & 211.75 & $a b$ & 46.53 & $\mathrm{a}$ \\
\hline 9 & 131 & 214.37 & $a b$ & 47.53 & $\mathrm{a}$ \\
\hline 10 & 132 & 218.62 & $a b$ & 47.37 & $\mathrm{a}$ \\
\hline 11 & 133 & 209.75 & $a b$ & 48.47 & $\mathrm{a}$ \\
\hline 12 & 134 & 225.50 & $a b$ & 48.64 & $\mathrm{a}$ \\
\hline 13 & 141 & 220.37 & $a b$ & 50.92 & $\mathrm{a}$ \\
\hline 14 & 142 & 220.37 & $a b$ & 48.05 & $\mathrm{a}$ \\
\hline 15 & 143 & 225.00 & $a b$ & 49.87 & $\mathrm{a}$ \\
\hline 16 & 144 & 236.87 & $\mathrm{a}$ & 51.50 & $\mathrm{a}$ \\
\hline 17 & 211 & 220.50 & $a b$ & 45.54 & $\mathrm{a}$ \\
\hline 18 & 212 & 220.87 & $a b$ & 48.99 & $\mathrm{a}$ \\
\hline 19 & 213 & 222.00 & $a b$ & 48.30 & $\mathrm{a}$ \\
\hline 20 & 214 & 214.00 & $a b$ & 46.80 & $\mathrm{a}$ \\
\hline 21 & 221 & 226.25 & $a b$ & 48.84 & $\mathrm{a}$ \\
\hline 22 & 222 & 222.12 & $a b$ & 51.07 & $\mathrm{a}$ \\
\hline 23 & 223 & 212.75 & $a b$ & 49.35 & $\mathrm{a}$ \\
\hline 24 & 224 & 219.00 & $a b$ & 49.18 & $\mathrm{a}$ \\
\hline 25 & 231 & 205.25 & $\mathrm{~b}$ & 48.04 & $\mathrm{a}$ \\
\hline 26 & 232 & 217.62 & $a b$ & 49.23 & $\mathrm{a}$ \\
\hline 27 & 233 & 214.87 & $a b$ & 50.18 & $\mathrm{a}$ \\
\hline 28 & 234 & 221.75 & $a b$ & 49.43 & $\mathrm{a}$ \\
\hline 29 & 241 & 223.12 & $a b$ & 49.78 & $\mathrm{a}$ \\
\hline 30 & 242 & 212.25 & $a b$ & 49.05 & $\mathrm{a}$ \\
\hline 31 & 243 & 218.50 & $a b$ & 49.41 & $\mathrm{a}$ \\
\hline 32 & 244 & 224.00 & $a b$ & 51.65 & $\mathrm{a}$ \\
\hline 33 & 311 & 210.00 & $a b$ & 46.14 & $\mathrm{a}$ \\
\hline 34 & 312 & 220.50 & $a b$ & 49.67 & $\mathrm{a}$ \\
\hline
\end{tabular}




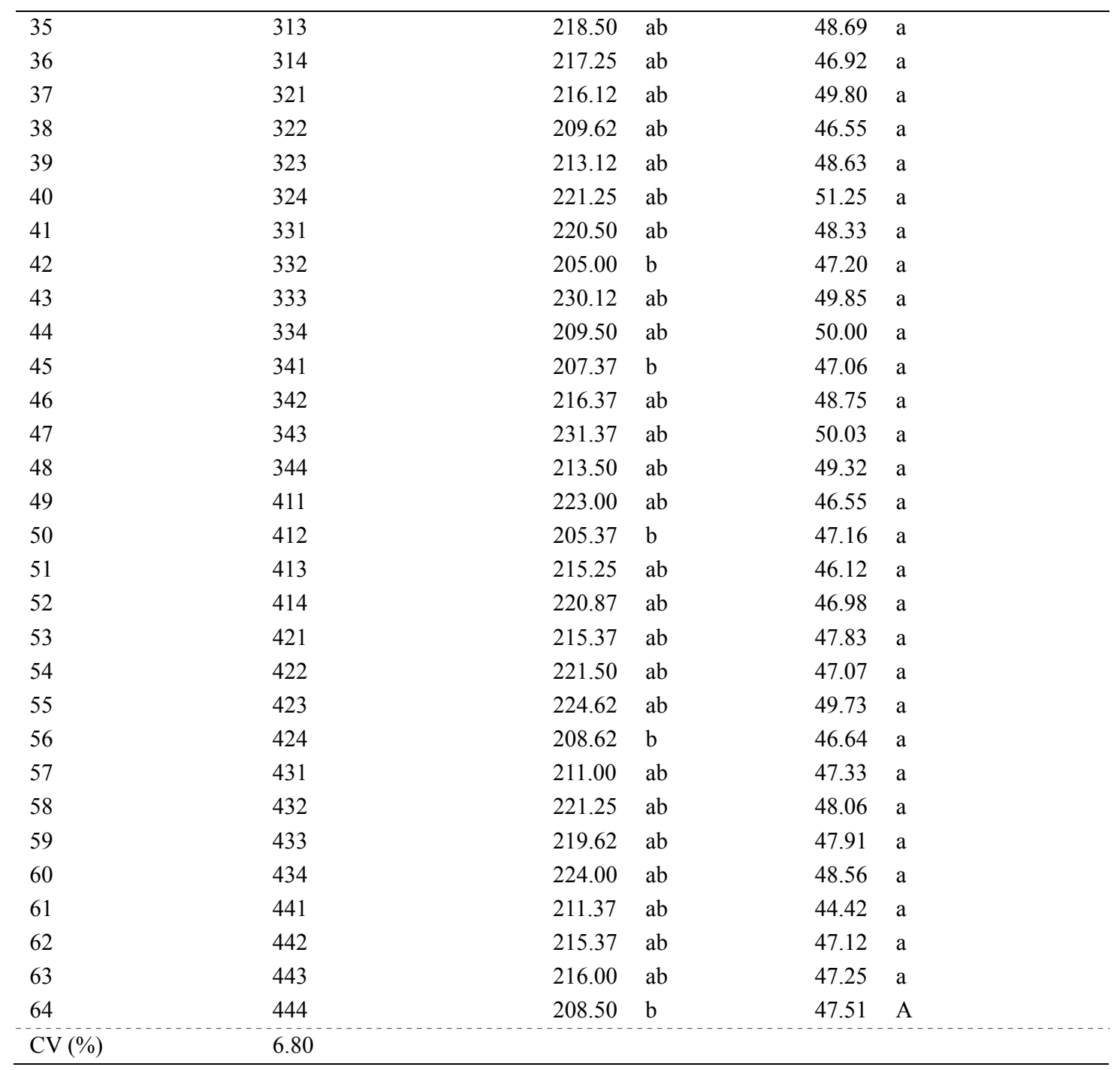

All the herein tested treatments showed better biometric parameters than the control. Treatment 16 (1-4-4) showed the best plant height results. The worse results were found in treatments 1, 25, 42, 45, 50, 56 and 64, which used high $\mathrm{N}$ doses and/or low $\mathrm{P}$ and/or $\mathrm{K}$ doses. These results corroborate the trends shown in Figures 4, 5 and 6.

According to Souza et al. (2006), forest species showed different behavioral features in response to fertilization. However, studies about the nutrition of Khaya ivorensis species remain incipient, fact that makes it difficult to compare results. Thus, it is worth continuing the current research, as well as conducting new studies about such species.

\section{Conclusion}

Based on the herein found results and according to the experimental conditions, it can be concluded that: 1) Liming and mineral fertilization are essential to the development of African mahogany plants; 2) The 55\% base saturation increase is satisfactory for the development of Khay a ivorensis plants; 3 ) The studied species is able to develop when it is subjected to small amounts of fertilizers and it is very tolerant to the excess of nutrients; 4) Among the herein studied macronutrients, only the excess of $\mathrm{N}$ has negatively influenced the plant growth. However, the crop showed no significant losses up to the herein tested limit; 5) Finally, the best treatment was the one that used the minimum $\mathrm{N}$ dose along with the maximum $\mathrm{P}$ and $\mathrm{K}$ doses.

\section{Acknowledgements}

We thank the financial support of the Universidade Federal de Goiás and Instituto Federal Goiano. 


\section{References}

ABRAF. (2014). Anuário estatístico ABRAF 2013 ano base 2012. Brasília, ABRAF. Retrieved from http://www.abraflor.org.br/estatisticas.asp

Benites, V. M. B., Carvalho, M. C. S., \& Resende, A. V. (2010). Potássio, cálcio e magnésio. In L. I. Prochnow, V. Casarin, \& S. R. Stipp (Eds.), Boas práticas para uso eficiente de fertilizantes (pp. 135-204). IPNI, Piracicaba.

Ciriello, V., Guerrini, I. A., \& Backes, C. (2014). Doses de nitrogênio no crescimento inicial e nutrição de plantas de guanandi. Cerne, 20, 653-660. https://doi.org/10.1590/01047760201420041445

Corcioli, G., Borges, J. D., \& Jesus, R. P. (2014). Sintomas de deficiência nutricional de macronutrientes em mudas de Khaya ivorensis cultivadas em solução nutritiva. Pesquisa Florestal Brasileira, 34, 59-164. https://doi: 10.4336/2014.pfb.34.78.641

Falesi, I. C., \& Baena, A. R. C. (1999). Mogno-africano Khaya ivorensis A. Chev. em sistema silvipastoril com leguminosa e revestimento natural do solo. Embrapa Amazônia Oriental, Belém. Retrieved from https://www.infoteca.cnptia.embrapa.br/handle/doc/388796

Favare, L. G., Guerrini, I. A., \& Backes, C. (2012). Níveis crescentes de saturação por bases e desenvolvimento inicial de teca em um latossolo de textura média. Ciência Florestal, 22, 693-702. https://doi.org/10.5902/ 198050987551

Feitosa, D. G., Maltoni, K. L., Cassiolato, K. M. R., \& Paiano, M. O. (2011). Crescimento de mudas de gonçalo-alves (Astronium fraxinifolium) sob diferentes fontes e doses de nitrogênio. Revista Árvore, 35, 401-411. https://doi.org/10.1590/S0100-67622011000300004

Lemmens, R. H. M. J. (2014). In D. Loupe, A. A. Oteng-Amoako, \& M. Brink (Eds.), Khaya ivorensis A. Chev-Dados de Protabase. PROTA (Plant Resources of Tropical Africa/Ressoucers Végétable de l'Afrique Tropicale). Retrieved from http://www.prota4u.org/search.asp

Mews, C. L., Sousa, J. R. L., Azevedo, G. T. O. S., \& Souza, A. M. (2015). Efeito do Hidrogel e Ureia na Produção de Mudas de Handroanthus ochraceus (Cham.) Mattos. Floresta e Ambiente, 22, $107-116$. https://doi.org/10.1590/2179-8087.080814

Moreno, J. L., Bastida, F., Ondono, S., Garcia, C., Andrés-Abellán, M., \& López-Serrano, F. R. (2017). Agro-forestry management of Paulownia plantations and their impact on soil biological quality: The effects of fertilization and irrigation treatments. Applied Soil Ecology, 117-117, 46-56. https://doi.org/10.1016/ j.apsoil.2017.05.001

Moretti, B. S., Furtini-Neto, A. E., \& Pinto, S. I. C. (2011). Crescimento e nutrição mineral de mudas de cedro australiano 453 (Toona ciliata) sob omissão de nutrientes. Cerne, 17, 453-463. https://doi.org/10.1590/ S0104-77602011000400003

Nikler, D. G., Bevege, D. I., Dickinson, G. R., Griffiths, M. W., Reilly, D. F., \& Lee, D. J. (2008). Developing African mahogany (Khaya senegalensis) germplasm and its management for a sustainable forest plantation industry in northern Australia: Progress and needs. Australian Forestry, 71, 33-47. https://oi.org/10.1080/ 00049158.2008.10676269

Nikles, D. G., \& Dickinson, G. R. (2012). Rapid microsatellite marker development for African mahogany (Khaya senegalensis, Meliaceae) using next-generation sequencing and assessment of its intra-specific genetic diversity. Molecular Ecology Resources, 12, 344-353. https://doi.org/10.1111/j.1755-0998.2011. 03080.x

Ravindran, P., Costa, A., Soares, R., \& Wiedenhoeft, A. C. (2018). Classification of CITES-listed and other neotropical Meliaceae wood images using convolutional neural networks. Plant Methods, 14, 1-10. https://doi.org/10.1186/s13007-018-0292-9

Ribeiro, A., Filho, A. C. F., \& Scolforo, J. R. S. (2017). African Mahogany (Khaya spp.) Cultivation and the Increase of the Activity in Brazil. Floresta e Ambiente, 24, e00076814. https://doi.org/10.1590/2179-8087. 076814

Ribeiro, A., Filho, A. C. F., Tomé, M., \& Scolforo, J. R. S. (2016). Site quality curves for African mahogany plantations in Brazil. Cerne, 22, 438-448. https://doi.org/10.1590/01047760201622042185 
Santana, R. C., Barros, N. F., \& Neves, J. C. L. (2002). Eficiência de utilização de nutrientes e sustentabilidade da produção em procedências de Eucalyptus grandis e Eucalyptus saligna em sítios florestais do estado de São Paulo. Revista Árvore, 26, 447-457. https://doi.org/10.1590/S0100-67622002000400007

Santini, D., Benedetti, E. L., Bastos, M. C., Kaseker, J. F., Reissmann, C. B, Brondani, G. E., \& Barros, N. F. (2013). Crescimento e nutrição de erva-mate influenciados pela adubação nitrogenada, fosfatada e potássica. Ciência Florestal, 23, 363-375. https://doi.org/10.5902/198050989282

Santos, R. A., Tucci, C. A. F., Hara, F. A. Z., \& Silva, W. G. (2008). Adubação fosfatada para a produção de mudas de mogno (Swietenia macrophylla King). Acta Amazonica, 38, 453-458. https://doi.org/10.1590/ S0044-59672008000300009

SFB (Serviço Florestal Brasileiro), \& IPAM (Instituto de Pesquisa Ambiental da Amazônia). (2011). Florestas Nativas de Produção Brasileiras (Relatório Técnico). Brasília, Distrito Federal. Retrieved from http://www.florestal.gov.br/documentos/publicacoes/1785-relatorio-tecnico-florestas-nativas-de-producao-b rasileiras/file

Silva, A. R. M., Tucci, C. A. F., Lima, H. N., \& Figueiredo, A. F. (2007). Doses crescentes de corretivo na formação de mudas de mogno (Swietenia macrophylla King). Acta Amazonica, 37, 195-200. https://doi.org/10.1590/S0044-59672007000200004

Souza, C. A. S., Tucci, C. A. F., Silva, J. F., \& Ribeiro, W. O. (2010). Exigências nutricionais e crescimento de plantas de mogno (Swietenia macrophylla King.). Acta Amazonica, 40, 515-522. https://doi.org/10.1590/ S0044-59672010000300010

Souza, N. H., Marchetti, M. E., Carvenali, T. O., Ramos, D. D., Scalon, S. P. Q., \& Silva, E. F. (2012). Estudo nutricional da canafístula (ii): Eficiência nutricional em função da adubação com nitrogênio e fósforo. Revista Árvore, 36, 803-812. https://doi.org/10.1590/S0100-67622012000500002

Souza, P. A., Venturin, N., \& Macedo, L. R. G. (2006). Adubação mineral do ipê-roxo (Tabebuia impetiginosa). Ciência Florestal, 16, 261-270. https://doi.org/10.5902/198050981907.

Tucci, C. A. F., \& Pinto, F. (2003). Nitrogen in the production of seedlings of mahogany [CD-ROM]. Brazilian Congress of Soil Science, 29. Ribeirão Preto.

Tucci, C. A. F., Lima, H. N., \& Lessa, J. F. (2009). Adubação nitrogenada na produção de mudas de mogno (Swietenia macrophylla King). Acta Amazonica, 39, 289-294. https://doi.org/10.1590/S0044-596720 09000200007

Tucci, C. A. F., Santos, J. C. L., \& Silva-Júnior, C. H. (2011). Desenvolvimento de mudas de Swietenia macrophylla em resposta a nitrogênio, fósforo e potássio. Floresta, 41, 471-490. https://doi.org/10.5380/ rf.v41i3.24039

Turner, B. J., Brenes-Arguedas, T., \& Condit, R. (2018). Pervasive phosphorus limitation of tree species but not communities in tropical forests. Nature, 555, 367-370. https://doi.org/10.1038/nature25789

Zanetti, R., Abreu, C. S., Silveira, S. H. P., \& Andrade, E. D. (2017). First report of Hypsipyla grandella (Lepidoptera: Pyralidae) on African mahogany. Scientia Agricola, 74, 492-494. https://doi.org/10.1590/ 1678-992X-2016-0362 


\section{Appendix}

Appendix 1. Urea, triple superphosphate and potassium chloride amounts applied to each lot and total amount used per treatment, at Hiroshi Okajima Experimental Station (Bonfinópolis, GO, Brazil)

\begin{tabular}{|c|c|c|c|c|c|c|c|c|c|}
\hline \multirow{3}{*}{ Treatment } & \multicolumn{3}{|c|}{ Urea } & \multicolumn{3}{|c|}{ Triple Superphosphate } & \multicolumn{3}{|c|}{ Potassium Chloride } \\
\hline & \multicolumn{2}{|c|}{ Application } & \multirow{2}{*}{ Total } & \multicolumn{2}{|c|}{ Application } & \multirow{2}{*}{ Total } & \multicolumn{2}{|c|}{ Application } & \multirow{2}{*}{ Total } \\
\hline & 1 and 2 & 3 and 4 & & 1 and 2 & 3 and 4 & & 1 and 2 & 3 and 4 & \\
\hline & -- & 1 & ------- & ----" & --- g & & ---- & -----"--" & ----- \\
\hline 1 & 0 & 0 & 0 & 0 & 0 & 0 & 0 & 0 & 0 \\
\hline 2 & 10 & 20 & 60 & 10 & 20 & 60 & 7 & 14 & 42 \\
\hline 3 & 10 & 20 & 60 & 10 & 20 & 60 & 14 & 28 & 84 \\
\hline 4 & 10 & 20 & 60 & 10 & 20 & 60 & 21 & 42 & 126 \\
\hline 5 & 10 & 20 & 60 & 10 & 20 & 60 & 28 & 56 & 168 \\
\hline 6 & 10 & 20 & 60 & 20 & 40 & 120 & 7 & 14 & 42 \\
\hline 7 & 10 & 20 & 60 & 20 & 40 & 120 & 14 & 28 & 84 \\
\hline 8 & 10 & 20 & 60 & 20 & 40 & 120 & 21 & 42 & 126 \\
\hline 9 & 10 & 20 & 60 & 20 & 40 & 120 & 28 & 56 & 168 \\
\hline 10 & 10 & 20 & 60 & 30 & 60 & 180 & 7 & 14 & 42 \\
\hline 11 & 10 & 20 & 60 & 30 & 60 & 180 & 14 & 28 & 84 \\
\hline 12 & 10 & 20 & 60 & 30 & 60 & 180 & 21 & 42 & 126 \\
\hline 13 & 10 & 20 & 60 & 30 & 60 & 180 & 28 & 56 & 168 \\
\hline 14 & 10 & 20 & 60 & 40 & 80 & 240 & 7 & 14 & 42 \\
\hline 15 & 10 & 20 & 60 & 40 & 80 & 240 & 14 & 28 & 84 \\
\hline 16 & 10 & 20 & 60 & 40 & 80 & 240 & 21 & 42 & 126 \\
\hline 17 & 10 & 20 & 60 & 40 & 80 & 240 & 28 & 56 & 168 \\
\hline 18 & 20 & 40 & 120 & 10 & 20 & 60 & 7 & 14 & 42 \\
\hline 19 & 20 & 40 & 120 & 10 & 20 & 60 & 14 & 28 & 84 \\
\hline 20 & 20 & 40 & 120 & 10 & 20 & 60 & 21 & 42 & 126 \\
\hline 21 & 20 & 40 & 120 & 10 & 20 & 60 & 28 & 56 & 168 \\
\hline 22 & 20 & 40 & 120 & 20 & 40 & 120 & 7 & 14 & 42 \\
\hline 23 & 20 & 40 & 120 & 20 & 40 & 120 & 14 & 28 & 84 \\
\hline 24 & 20 & 40 & 120 & 20 & 40 & 120 & 21 & 42 & 126 \\
\hline 25 & 20 & 40 & 120 & 20 & 40 & 120 & 28 & 56 & 168 \\
\hline 26 & 20 & 40 & 120 & 30 & 60 & 180 & 7 & 14 & 42 \\
\hline 27 & 20 & 40 & 120 & 30 & 60 & 180 & 14 & 28 & 84 \\
\hline 28 & 20 & 40 & 120 & 30 & 60 & 180 & 21 & 42 & 126 \\
\hline 29 & 20 & 40 & 120 & 30 & 60 & 180 & 28 & 56 & 168 \\
\hline 30 & 20 & 40 & 120 & 40 & 80 & 240 & 7 & 14 & 42 \\
\hline 31 & 20 & 40 & 120 & 40 & 80 & 240 & 14 & 28 & 84 \\
\hline 32 & 20 & 40 & 120 & 40 & 80 & 240 & 21 & 42 & 126 \\
\hline 33 & 20 & 40 & 120 & 40 & 80 & 240 & 28 & 56 & 168 \\
\hline 34 & 30 & 60 & 180 & 10 & 20 & 60 & 7 & 14 & 42 \\
\hline 35 & 30 & 60 & 180 & 10 & 20 & 60 & 14 & 28 & 84 \\
\hline 36 & 30 & 60 & 180 & 10 & 20 & 60 & 21 & 42 & 126 \\
\hline 37 & 30 & 60 & 180 & 10 & 20 & 60 & 28 & 56 & 168 \\
\hline 38 & 30 & 60 & 180 & 20 & 40 & 120 & 7 & 14 & 42 \\
\hline 39 & 30 & 60 & 180 & 20 & 40 & 120 & 14 & 28 & 84 \\
\hline 40 & 30 & 60 & 180 & 20 & 40 & 120 & 21 & 42 & 126 \\
\hline 41 & 30 & 60 & 180 & 20 & 40 & 120 & 28 & 56 & 168 \\
\hline 42 & 30 & 60 & 180 & 30 & 60 & 180 & 7 & 14 & 42 \\
\hline 43 & 30 & 60 & 180 & 30 & 60 & 180 & 14 & 28 & 84 \\
\hline 44 & 30 & 60 & 180 & 30 & 60 & 180 & 21 & 42 & 126 \\
\hline 45 & 30 & 60 & 180 & 30 & 60 & 180 & 28 & 56 & 168 \\
\hline 46 & 30 & 60 & 180 & 40 & 80 & 240 & 7 & 14 & 42 \\
\hline 47 & 30 & 60 & 180 & 40 & 80 & 240 & 14 & 28 & 84 \\
\hline 48 & 30 & 60 & 180 & 40 & 80 & 240 & 21 & 42 & 126 \\
\hline 49 & 30 & 60 & 180 & 40 & 80 & 240 & 28 & 56 & 168 \\
\hline
\end{tabular}




\begin{tabular}{llllllllll}
\hline 50 & 40 & 80 & 240 & 10 & 20 & 60 & 7 & 14 & 42 \\
51 & 40 & 80 & 240 & 10 & 20 & 60 & 14 & 28 & 84 \\
52 & 40 & 80 & 240 & 10 & 20 & 60 & 21 & 42 & 126 \\
53 & 40 & 80 & 240 & 10 & 20 & 60 & 28 & 56 & 168 \\
54 & 40 & 80 & 240 & 20 & 40 & 120 & 7 & 14 & 42 \\
55 & 40 & 80 & 240 & 20 & 40 & 120 & 14 & 28 & 84 \\
56 & 40 & 80 & 240 & 20 & 40 & 120 & 21 & 42 & 126 \\
57 & 40 & 80 & 240 & 20 & 40 & 120 & 28 & 56 & 168 \\
58 & 40 & 80 & 240 & 30 & 60 & 180 & 7 & 14 & 42 \\
59 & 40 & 80 & 240 & 30 & 60 & 180 & 14 & 28 & 84 \\
60 & 40 & 80 & 240 & 30 & 60 & 180 & 21 & 42 & 126 \\
61 & 40 & 80 & 240 & 30 & 60 & 180 & 28 & 56 & 168 \\
62 & 40 & 80 & 240 & 40 & 80 & 240 & 7 & 14 & 42 \\
63 & 40 & 80 & 240 & 40 & 80 & 240 & 14 & 28 & 84 \\
64 & 40 & 80 & 240 & 40 & 80 & 240 & 21 & 42 & 126 \\
& 40 & 80 & 240 & 40 & 80 & 240 & 28 & 56 & 168 \\
\hline
\end{tabular}

Appendix 2. Summary of variance analysis showing the degrees of freedom (DF), mean square (MS), significance level and coefficient of variation for variables such as height (h) and root collar diameter (rcd) according to N, $P$ and $K$ doses applied to African mahogany (Khaya ivorensis) plants grown at Hiroshi Okajima Experimental Station (Bonfinópolis, GO, Brazil)

\begin{tabular}{llll}
\hline Variation source & DF & MSh & MSrcd \\
\hline $\mathrm{N}$ & 3 & $112.18^{\mathrm{ns}}$ & $76.20^{*}$ \\
$\mathrm{P}$ & 3 & $326.75^{\mathrm{ns}}$ & $39.01^{\mathrm{ns}}$ \\
$\mathrm{K}$ & 3 & $242.44^{\mathrm{ns}}$ & $27.52^{\mathrm{ns}}$ \\
$\mathrm{NP}$ & 9 & $410.88^{\mathrm{ns}}$ & $19.45^{\mathrm{ns}}$ \\
$\mathrm{NK}$ & 9 & $311.58^{\mathrm{ns}}$ & $4.55^{\mathrm{ns}}$ \\
$\mathrm{PK}$ & 9 & $229.83^{\mathrm{ns}}$ & $10.05^{\mathrm{ns}}$ \\
$\mathrm{NPK}$ & 27 & $481.64^{* *}$ & $15.63^{\mathrm{ns}}$ \\
Block & 7 & $307.15^{\mathrm{ns}}$ & $371.24^{* *}$ \\
Residue & 441 & 225.32 & 15.06 \\
\hline Total & 511 & 6.92 & 8.02 \\
\hline CV\% & & & \\
\hline
\end{tabular}

Note. ${ }^{\text {ns: }}$ : non-significant according to the Tukey test, at $5 \%$ probability level; $*$ : significant according to the Tukey test, at $5 \%$ probability level; **: significant according to the Tukey test, at $1 \%$ probability level.

Appendix 3. Summary of variance analysis showing the degrees of freedom (DF), mean square (MS), significance level and coefficient of variation for variables such as height (h) and root collar diameter (rcd) according to the NPK fertilization treatments conducted at Hiroshi Okajima Experimental Station (Bonfinópolis, GO, Brazil)

\begin{tabular}{llll}
\hline Variation source & DF & MSh & MSrcd \\
\hline Treatment & 64 & $705.7889^{* *}$ & $36.8516^{* *}$ \\
Block & 7 & $315.1228^{\text {ns }}$ & $369.9585^{* *}$ \\
Residue & 448 & 215.7344 & 15.6099 \\
\hline Total & 519 & $6.80 \%$ & $8.19 \%$ \\
\hline CV\% & & \\
\hline
\end{tabular}

Note. ${ }^{\text {ns: }}$ non-significant according to the Tukey test, at $5 \%$ probability level; ${ }^{* *}$ : significant according to the Tukey test, at $1 \%$ probability level.

\section{Copyrights}

Copyright for this article is retained by the author(s), with first publication rights granted to the journal.

This is an open-access article distributed under the terms and conditions of the Creative Commons Attribution license (http://creativecommons.org/licenses/by/4.0/). 